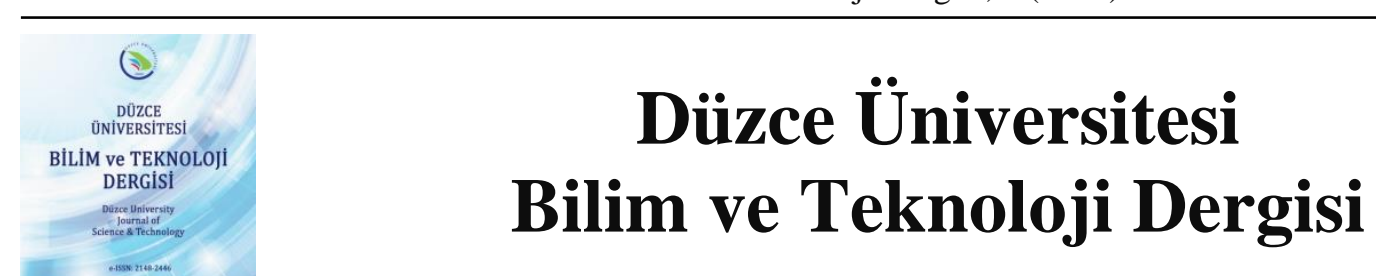

Derleme Makalesi

\title{
Probiyotik Peynirlerle İlgili Araştırmalar ve Endüstrideki Uygulamaları
}

\author{
(iDNilüfer Sena AYDOĞDU ${ }^{\text {a }}$, iD Tuğba KÖK TAŞ ${ }^{\mathrm{a} *}$ \\ ${ }^{a}$ Gıda Mühendisliği Bölümü, Mühendislik Fakültesi, Süleyman Demirel Üniversitesi, Isparta, TÜRKIYYE \\ * Sorumlu yazarın e-posta adresi: tugbakoktas@sdu.edu.tr \\ DOI:10.29130/dubited.874869
}

\begin{abstract}
$\underline{\mathrm{OZZ}}$
Günlük hayatımızda probiyotik, fonksiyonel gıdalar, nutrasötikler ve sağlıklı beslenme gibi kelimeleri daha bilinçli kullandıkça raflarda bunlara yönelik ürünlere olan talep de artmaktadır. Endüstri ise gelişen teknolojik uygulamalar, bilime ulaşma kolaylığı ve Ar-Ge çalışmalarına verilen önemle bu tarz ürünleri raflara koymakta yarışmaktadır. Probiyotiklerin gıda alanında özellikle süt ürünlerinde daha sık kullanımı dikkat çekicidir. Farklı probiyotik mikroorganizmaların kullanımı bu sayısal üstünlüğü sağlamada destekleyen unsurdur. Yanı sıra süt ürünleri yelpazesinin genişliği ve süt ürünlerinin bu mikroorganizmalar için uygun ortam oluşu probiyotik ürün çeşitliliğini sağlamaktadır. Süt endüstrisinde probiyotikler en çok yoğurt ürününde kullanılmaktadır, peynirde daha az kullanılmasının nedenlerinin en başında, uzun raf ömrü süresince probiyotik mikroorganizma sayısının korunamaması gelmektedir. $\mathrm{Bu}$ derlemede, probiyotikler, probiyotiklerle zenginleştirilmiş peynirler ile ilgili araştırmalar, kullanılan kültürlerin ürün kalitesindeki etkileri ve peynirlerin üretiminde probiyotik mikroorganizmaların canlılığını etkileyen faktörler ile ilgili yapılan çalışmalar incelenmiştir. Ayrıca Türkiye ve dünyada probiyotik peynir üretimi değerlendirilmiştir. Probiyotik mikroorganizmaların biyoyararlılıkları sebebiyle alternatif ürün olarak probiyotik peynir üretiminin teşvik edilmesi önerilmektedir.
\end{abstract}

Anahtar Kelimeler:Probiyotik, Peynir üretimi, Alternatif ürünler

\section{Research on Probiotic Cheese and Its Applications in Industry}

\begin{abstract}
As we use words such as probiotics, functional foods, nutraceuticals and healthy nutrition more consciously in ourdaily life, the demand for products for these on theshelvesincreases. The industry, on theotherhand, competes in putting such products on theshelves with developing technological applications, ease of Access to science and the importance given to R\&D studies. It is noteworthy that probiotics are more frequently used in food, especially in dairy products. The use of different probiotic microorganisms supports this numerical advantage. In addition, the wide range of dairy products and the suitable environment for these microorganisms provide probiotic product diversity. In the dairy industry, probiotics are mostly used in yogurt products the main reason for lessuse in cheese is that the number of probiotic microorganisms can not be preserved during the long shelf life. In this review, probiotics, research on probiotic-enriched cheeses, the effects of the cultures used on the product quality and the factors affecting thev iability of probiotic microorganisms in the production of cheeses were examined. It is also evaluated Turkey and the world in the production of probiotic cheese. Due to the bioavailability of probiotic microorganisms, it is recommended to encourage the production of probiotic cheese as an alternative product.
\end{abstract}

Keywords:Probiotic, Cheese production, Alternative products 


\section{GIRIS}

Fonksiyonel gıdalar, doğal besin değeri dışında insan sağlığına fayda sağlayan gıdalardır [1]. Dünya çapında sağlık bilincine sahip tüketiciler arasında popülerlik ve besin açısından daha zengin gıda ürünlerine yönelik tercihlerin artması, spesifik olarak antibiyotiklerin dirençliliklerinin artması, artan yaşlı nüfus oranı ve çocuklar için probiyotik kullanımının öneminin artması probiyotiklere olan talebi de artırarak bu pazarın büyümesini desteklemektedir. Probiyotik mikroorganizmaların suş çeşitlerinin belirlenmesi ve çeşitli formlarda (sıvı, kuru, macun gibi) hazırlanmaları, çok farklı ürün türlerine (fonksiyonel yiyecek ve içecekler, tıbbi, diyet takviyeleri ve hayvan yemi gibi) uygulanabilmesine olanak sağlamaktadır. Probiyotik bakteri en fazla farmokolojik alan için üretilirken ikinci sırada gida sektörü gelmektedir [2]. Çünkü probiyotik kültürler gidaya eklendiğinde, tüketicinin rutinini değiştirmeden günlük diyetine gireceğinden, tüketimi kolaylaştırabilir [3]. Bu segmentin büyük pay1 özellikle süt ürünlerinde (fermente süt, yoğurt ve peynir gibi) probiyotiklerin artan kullanımına bağlanmaktadır [2]. Ayrıca büyüyen gastrointestinal ve ekstraintestinal bozukluklar (antibiyotikle ilişkili ishalin önleme ve hafifletme semptomları, iltihaplı bağırsak hastalığı, laktoz intoleransı ve hassas/huzursuz bağırsak sendromu dahil) probiyotik tercihini artırmaktadır. Probiyotiklerin, serum kolesterolünü azaltma, gastrointestinal enfeksiyonlar üzerinde antimikrobiyal aktivite, antimutajenik, antikarsinojenik, bağırsak sağlığını düzenleyici özelliği, bağışıklık sistemini güçlendirme ve Helicobacter pylori enfeksiyonunun baskılanması gibi sağlı üzerine birçok olumlu etkileri belirtilmektedir [4]. Probiyotiklerin gıdalara eklenmesi olumlu sağlık etkilerinin yanında ürünün tadına, lezzetine, rengine, dokusuna, besin değerine ve raf ömrüne olumlu katkı da bulunmaktadır [5]. Probiyotik ile ilgili yapılan çok farklı araştırmaların yapılmasıyla, fonksiyonel gıdalar grubunda tanımlanan probiyotik ürünler de pazara hızla girmektedir [6,7]. Fonksiyonel gıda üreticileri de bu yararlı bakterileri farklı gıda ürünlerinde kullanarak ürün yelpazelerini artırmaya devam etmektedir [6].

\section{PROBIYYTIKLER}

Probiyotik kelime anlamı olarak "yaşam için" anlamında olup, "mikrobiyal dengesini geliştirerek konakçının sağlığını olumlu yönde etkileyen canlı mikroorganizmalar" olarak tanımlanan bir terimdir [8]. Bir bakterinin probiyotik olarak kabul edilmesi için çeşitli kriterlere sahip olması gerekmektedir [9]. Probiyotik olarak tanımlanacak bir mikroorganizmanın kriterleri arasında, suşun insan kaynaklı olması, insan kullanımı için güvenli olması, asit ve safrada stabil olması ve bağırsak mukozasına uyması bulunmaktadır [10]. Probiyotiklerin sağlı üzerine etkilerinden faydalanmak için probiyotik bakteriler, gıdaların raf ömrünün sonuna kadar depolama yoluyla bu canlılığı korumalı ve uygun organoleptik özellikleri sağlamalıdır [9]. Tüketilen üründe canlı probiyotik bakteriler $10^{6} \mathrm{kob} / \mathrm{g}$ oranında mevcut olmalıdır [11].

Probiyotik olarak Lactobacillus, Leuconostoc, Pediococcus, Bifidobacterium ve Enterococcus türlerine ait farklı cinslerde ve suşlarda birçok bakteri ve maya kullanılır ancak probiyotik özelliklere sahip bakterilerin başında Lactobacillus acidophilus, Lactobacillus rhamnosus, Lactobacillus casei ve Bifidobacterium bifidum, Bifidobacterium longum gelmektedir $[4,10]$.

\section{PEYNIRDE PROBIYYOTIKLERIN KULLANIMI ILE ILGILII YAPILAN BAZI ARASTIRMALAR}

Probiyotiklerin sağlık üzerine etkilerinden faydalanmak için tüketilen üründe uygun bileșenler, gıda matrisleri ve üretim yöntemleri seçilerek probiyotiklerin canlılıkları sağlanmalıdır [5]. Süt ürünleri probiyotik bakterilerin insan bağırsağına iletilmesinde önemli bir yere sahiptir çünkü bu oluşan fermente ürünler probiyotik bakterilere canlılıklarının devamlılığı için uygun bir ortam sağlar [12]. 
Fermente süt ürünlerinden peynir, sütün doğrudan ya da pastörize edildikten sonra asit veya enzim ile pıhtılaştırılması, pıhtıdan peyniraltı suyunun ayrılması ve pıhtının farklı şekillerde işlenmesi ile elde edilen bir süt ürünüdür [13]. Aynı zamanda peynirin besleyici yönü olması sebebiyle önemli gıda ürünlerinden biridir, çeşitliliğinin fazla olması tüketici kitlesi açısından zengin ve tüm yaş grupları için uygundur. Bu nedenle alternatif bir probiyotik gıda olarak birçok pazarlama stratejisi için firsatlar sunmaktadır [14]. Probiyotik peynirlerin uygulamaları ile ilgili ele alınan süzme peynir [15], Crescenza peyniri [16], kaşar peyniri [17], taze peynir [18], yarı sert peyniri [19] ve beyaz salamura peynir [20] gibi çalışmalar bulunmaktadır. Araştırmalar bireylerin probiyotik mikroorganizma alımına alternatif olarak peynirin büyük bir potansiyele sahip olduğunu göstermiştir.

Milesi vd. [21] yaptıkları bir çalışmada, starter olarak Streptococcus thermophilus kültürü kullanılırken probiyotik olarak dört laktobasil suşunun (Lactobacillus plantarum 191, L. casei 190, L. rhamnosus I73 ve 175 ) yumuşak Cremoso peyniri ve yarı sert Pategrás peynirinde proteolize ve duyusal profile katkısı incelenmiştir. $L$. plantarum 191 ve $L$. casei 190 yumuşak ve yarı sert peynirlerde orta derecede artmış ikincil proteolize neden olduğu, aşırı asitleşmediği ve peynirlerin duyusal profillerini olumlu yönde değiştirdiği gözlenmiştir. L. rhamnosus I73 ve I75 suşu, peynirin ikincil proteolizinde daha güçlü bir artış sergilediği ancak peynir genel kalitesini iyileştirmediği ve bazı durumlarda asidifikasyona neden olduğu gözlenmiştir. Uygulanan probiyotik bakterinin sayısal olarak artışı veya dengede oluşu, genel kaliteyi iyileştirmesi ile paralel olmadığı bilgisi, ürün kalitesi açısından önemlidir.

Probiyotik suşlar, gıda üretim süreci ile teknolojik olarak uyumlu olmalıdır. Probiyotik suşların peynire inokülasyon ile üretim ve olgunlaşma işlemi sırasında canlılığını koruyabilmesi ve/veya sayısının artması gerekmektedir [14].

Gardiner vd. [22] çalışmasında ise probiyotik Lactobacillus paracasei NFBC 338 ( Rif $^{\mathrm{r}}$ ) rifampisine dirençli bir kültür içeren yağsız süt tozu spreyle kurutularak Çedar peynirine ilave edilmiş, püskürtülerek kurutulmuş formdaki probiyotik kültür, soğutulmuş ve ya oda sıcaklığında depolama sırasında en az 7 hafta boyunca peynir kalitesini olumsuz etkilemeden stabil kalmıştır. Bu şekilde hazırlanan kültürler, ürünlere doğrudan ilave etmek için kullanılır böylece probiyotiklerin peynir kültürü ile ilgili etkileşim problemleri önlenebilir.

Bergamini vd. [23] çalışmalarında probiyotik kültür olarak $L$. acidophilus ve $L$. paracasei subsp. Paracasei Pategrás Argentino peynirinde kullanılmıştır. Kültürleri liyofilize ve aktif form olarak uygulamışlar ve liyofilize olarak probiyotiklerin doğrudan eklenmesi daha verimli olduğu tespit etmişler ve duyusal olarak olumsuzluk belirtmemişlerdir.

Gomes vd. [24] L. acidophilus LA-5 (0, 0.4 ve $0.8 \mathrm{~g} / \mathrm{L})$ farklı oranlarda ilavesi ile Minas taze peynirinin fizikokimyasal parametreleri ve duyusal kabulü üzerindeki etkisi araştırmıştır. Yüksek miktarda L. acidophilus eklenmesi, 20 gün boyunca 5 ve $7{ }^{\circ} \mathrm{C}$ 'de depolanan Minas taze peynirinin raf ömrü boyunca ürünün probiyotik durumunu koruyan bu mikroorganizmanın sayısının artmasına $(9.42$ ve $9.11 \operatorname{logkob} / \mathrm{g}$ ) neden olduğunu ancak bu araştırmada da organoleptik özelliklerinin azaldığ etmişlerdir.

Bergamini vd. [25] Pategrás Argentino peynirinin sütüne iki farklı yöntemle probiyotik uygulamas1, bu probiyotik kültürlerin olgunlaşma sırasında hayatta kalmalarını ve proteolize katkılarını karşılaştırmıştır. Üç farklı probiyotik kültür (L. acidophilus, L. paracasei ve Bifidobacterium lactis) hem tek kültür hem de üç türlü karışık kültür olarak peynir sütüne ilave edilmiştir. Üç suşlu karışık bir kültür olarak kullanıldığında sinerjik etki gözlenmiştir ve peynirin kabul edilebilirliği üzerinde olumlu etkisi olmuştur. Probiyotiklerin ön inkübasyonu, probiyotik mikroorganizma sayısını arttırmamıştır. Aynı zamanda $L$. acidophilus'un peynir uygulamalarında sekonder proteolizini arttırdığı gözlenmiştir.

Yapılan bir çalışma taze Arjantin peynirinin endüstriyel üretiminde Lactobacillus paracasei A13, Bifidobacterium bifidum A1 ve L. acidophilus A3 probiyotik bakterilerin canlılığın belirlemek için 5 ${ }^{\circ} \mathrm{C}$ ve $12{ }^{\circ} \mathrm{C}$ 'de 60 gün buzdolabında depolanmışlardır. Sonuç olarak Arjantin taze peynirinde bulunan 
L. paracasei A13, ürünün üretim süreci sirasında ve ürünün $5{ }^{\circ} \mathrm{C}$ 'de 15 . gün depolamada duyusal olarak olumsuz etkilemeden sayısını önemli düzeyde artırmışıtır ancak daha yüksek bir depolama sıcaklı̆̆ $12{ }^{\circ} \mathrm{C}$ 'de 60 . gün depolamada duyusal özellikleri negatif etkilediğini belirtmişlerdir[26].

Fortin vd. [27], oksijene duyarlı olduğu bilinen probiyotik Bifidobakter suşları (B. longum R0175, B. lactis BB-12, Bifidobacterium infantis ATCC 15697 ve B. longum ATCC 15708) kullanılarak üretilen Çedar peynirinde çözünmüş oksijen seviyesinin, sıcaklığın ve tuzlamanın kültürlerin canlılığı üzerindeki etkisi inceleyen önemli bir araştırmadır. Bu çalışmaya göre, probiyotik bakterilerinsuşları, inokülasyon miktarı ve uygulanan tuza göre peyniraltı suyu ve pıhtı kısmında probiyotik bakteri sayılarının \%29-92 arasında değiştiğini belirlemişlerdir. Tuzlama, işleme sırasında peynir altı suyu ile yaklaşık \%13 bakteri kaybına, depolama ile de 3 log kob/g canlılığı kaybına neden olduğunu bulmuşlardır.

Scheller ve O'Sullivan [28], yaptıkları çalışmada anaerobik bir ortamda $\mathrm{pH} 5.75$ 'e asitleştirilmiş $\mathrm{BLIM}+\mathrm{Fe}$ (ortamblim+Fe) varlığında hazırlanan B. longum DJO10A ve B. animalis subsp. lactis $\mathrm{Bb}$ 12 Çedar peynirine ilave edilmiş ve raf ömrü boyunca kültürlerin canlılığı üzerindeki etkisi değerlendirilmiştir. Yalnızca Bb-12 kullanılan peynirlerde aşılamanın \%133'ü kadar büyüyerek 8.00 logkob/g olduğu, olgunlaşma sırasında sayımların yüksek kaldığı ve 12 aylık bir dönemde bir log dan daha az azalma gösterdiği gözlenmiştir. Karışık Bb-12 ve DJO10A kültürü kullanan peynirlerde her iki suş daha düşük seviyelerde (\%3.02 ve 1.11) ilave edilmiştir ve artarak sırasıyla 6.00 ve 5.04 $\operatorname{logkob} / \mathrm{g}$ değerlerinde olduğu gözlenmiştir. Yapılan çalışma sonucunda öldürücü olmayan stres ortamında Bifidobakterilerin hazırlanmasının, peynire katılan canlı hücrelerin sayısını artırabildiği halde, peynir olgunlaşması sırasında canlılı̆̆ı etkilemediği bildirmiştir.

Minervini vd. [29] yaptıkları bir çalışmada, pasta filata peynir grubunda olan Fiordi Latte peynirine 1sıya dayanıklı probiyotik Lactobacillus türleri (L. casei, L. delbrueckii subsp. bulgaricus, $L$. paracasei, L. plantarum, L. rhamnosus ve L. reuteri) kullanılarak peyniri yapımı ve 14 gün depolanması sırasında probiyotik bakterilerin canlılığ araştırmıştır. Probiyotik suşların uygulanan 1sıl işlemlere dayanma kapasitesinin (65 veya $55^{\circ} \mathrm{C}$ 'de 10 dakika) önemli ölçüde değiştiği tespit edilmiştir. En yüksek canlılık $42^{\circ} \mathrm{C}^{\prime}$ de 30 dakika boyunca adapte edildiğinde gözlenmiştir.

Mirzaei vd. [30] yaptıkları bir çalışmada, probiyotik İran beyaz salamura peynirine serbest veya kalsiyum aljinat jeli ve dirençli nişasta ile ekstrüzyon tekniği kullanılarak mikrokapsülasyonu ile ilave edilen L. acidophilus LA-5'in 182 günlük depolama süresince canlı hücre sayısı değerlendirilmiştir. İlk günde serbest bakteri içeren peynirdeki ortalama canlı hücre sayıs1 $(10 \pm 0.58 \mathrm{log} \mathrm{kob} / \mathrm{g})$ mikrokapsüllenmiş bakteri $(12.32 \pm 0.35 \log \mathrm{kob} / \mathrm{g})$ içeren peynirden daha az olduğu belirlenmiştir. Her iki peynir türünde de saklama süresinin 28. gününden 182. gününe kadar azalma gözlenmiştir. Ancak serbest hücreler içeren peynirdeki azalma $(5.1 \pm 0.67 \mathrm{log} \mathrm{kob} / \mathrm{g})$, mikrokapsüllenmiş hücreler içeren peynirden $(11.00 \pm 0.58 \mathrm{log} \mathrm{kob} / \mathrm{g})$ daha yüksek olduğu belirlenmiştir. İran beyaz salamura peynirinde 6 aylık depolamadan sonra $L$. acidophilus LA-5'in canlı kalma oranını artırabildiği gözlenmiştir. Duyusal özellikleri değerlendirildiğinde mikrokapsül uygulamalı peynirlerin daha üstün olduğunu belirtmişlerdir. Bu araştırma probiyotik bakterinin mikrokapsülasyon ile canlı sayısına olumlu etkisi değerlendirilebilir.

Başka bir çalışmada B. bifidum BB-12 ve L. acidophilus LA-5ekstrüzyon veya bir emülsiyon tekniği ile mikrokapsüllenerek kaşar peynirine ilave edilmiş ve bakteri canlılığ incelenmiştir. 90 günlük depolama süresince iki kapsülleme tekniği arasında fark bulunmamıştır. Probiyotik bakterilerin canlılığı mikrokapsülleme ile büyük ölçüde korunduğu gösterilmiştir [31].

Özer vd. [12], B. bifidum BB-12 ve L. acidophilus LA-5'iekstrüzyon veya bir emülsiyon tekniği ile mikrokapsüllenerek beyaz salamura Türk peynirine ilave ederek canlılığı araştırmıştır. Probiyotik bakteri içerikli peynirlerde orta ve uzun zincirli serbest yağ asidi içerikleri, asetaldehit ve diasetil seviyelerinin kontrol peynirinden çok daha yüksek olduğu gözlenirken duyusal özellikler açısından farklılık olmadığını belirlemişlerdir. Bu araştırmada probiyotiklerin fermentasyona ve oluşan metabolitlere katkı sağladığı, organoleptik özelliklerine zarar vermediği belirtilmektedir. 
Ortakci vd. [9] yaptıkları çalışmada, düşük nemli yarı yağlı mozzarella peyniri üretimindeki pasta filata (peynir $55^{\circ} \mathrm{C}^{\prime}$ ye 1 sitılma ve $70{ }^{\circ} \mathrm{C}$ sicak tuzlu su içinde germe) işleminin ve depolanması sırasında aljinat mikrokapsüllerinde kapsüllenmesinin, probiyotik L. paracasei LBC-1'in canl1 kalma etkisi araştırılmıştır. Mozeralla peynirinin üretiminde haşlama işleminin serbest $\left(\sim 10^{10} \mathrm{kob} / \mathrm{g}\right)$ ve jel kapsüllenmiş $\left(\sim 5 \times 10^{8} \mathrm{kob} / \mathrm{g}\right)$ L. paracasei LBC-1 sayısında sirasiyla 0.4 ve $0.2 \operatorname{logkob} / \mathrm{g}$ azalmaya neden olduğunu tespit etmişlerdir. Bu araştırmada peynirde şekil vermede uygulanan 1 sıl işlemin bakteri düzeyinde olumsuz etkisi olduğunu, uygulanan kapsülasyon işlemininde canlı oranının korumada olumlu etkisi olduğunu belirtilmiştir.

Amine vd. [32] aljinat boncukları kullanılarak yapılan mikrokapsülasyonun (ME), Çedar peyniri üretimi ve 21 gün $4^{\circ} \mathrm{C}^{\prime}$ de depolanması sırasında $-80^{\circ} \mathrm{C}^{\prime}$ de donmuş B. longum $15708^{\prime}$ in simüle edilmiş gastrointestinal sistemde canlılığını araştırmıştır. Bu amaçla damlacık ekstrüzyon yöntemi (ADE) ve iki polimeri (doğal ve palmitoillenmişaljinat) içeren emülsiyon yöntemi karşılaştırılmıştır. Damlacık ekstrüzyon yöntemi kullanılarak üretilenler boncuklar kullanılarak ME tekniği, emülsiyon tekniği ile üretilenlerden $B$. longum daha uzun süre canlı kaldığı belirtilmiştir.

Kasımoğlu vd. [33] yaptıkları çalışmada, L. acidophilus 593N' in vakumda veya tuzlu suda depolanan Türk beyaz peynirlerinin olgunlaşması sırasında $L$. acidophilus 593N' in canlılı̆̆ına etkisini araştırmıştır. Vakum paketinde olgunlaşma yapılan peynirlerde L. acidophilus $593 \mathrm{~N}$ sağlık üzerindeki olumlu etkiler için gerekli olan $10^{7} \mathrm{kob} / \mathrm{g}$ sayılarına ulaşmıştır. Vakumlu paketlenmiş probiyotik peynir, en yüksek proteoliz seviyelerine ve duyusal skorlara sahip olduğu gözlenmiştir. Bu nedenle, probiyotik Türk beyaz peynirlerini depolamak için vakum paketleme tercih edilebileceği belirtilmiştir.

Yapılan bir çalışmada, koyun sütü kullanılarak yapılan Scamorza peynirine probiyotik suşların $(L$. acidophilus, B. longum ve B. lactis karışımı) dahil edilmesi ve peynir yapımı sırasında probiyotik bakterilerin hayatta kalması araştırılmıştır. Peynirlerdeki olgunlaşma işlemi, kullanılan probiyotiksuşa göre farklı şekilde etkilenmiştir. B. longum ve B. lactis suşlarının karışımı, peynirde daha fazla proteolizi gerçekleştirmiş ve daha karmaşık çözünür peptit oluşumuna yol açtığını belirtmişlerdir. $L$. acidophilus suşu ise lipolize sebep olmuş ve peynirde oleik asit ve konjüge linoleik asit içeriğini artırdığı gözlemişlerdir [34].

Başka bir çalışmada, Cremoso peynirlerinde (yumuşak peynir çeşidi) başlangıç kültürü olmayan laktobasillerin ve iki ek kültürün probiyotik performansı incelenmiştir. Çalıșmada laktobasil içermeyen bir kontrol peyniri ve $L$. plantarum $\mathrm{I91}$ ve $L$. paracasei $\mathrm{I} 90$ içeren iki deneysel peynir hazırlanmıştır. Seçilmiş laktobasil suşlarının kullanılması teknolojik ve probiyotik bir rol oynadığı, peynir kalitesinin standartlaşmasına katkıda bulunduğu gözlenmiştir [35].

Yapılan bir çalışmada, probiyotik Çedar peynirlerinin 24 hafta boyunca olgunlaşması sırasında, farklı olgunlaşma sicakliklarının $\left(4\right.$ ve $8^{\circ} \mathrm{C}$ ) probiyotik bakterilerin (B. longum 1941, L. casei 279 ve $L$. acidophilus 4962) hayatta kalması ve proteoliz üzerindeki etkisi araştırılmıştır. Probiyotik mikroorganizmalar 24 hafta boyunca hem 4 ve $8{ }^{\circ} \mathrm{C}$ 'de olgunlaşma sırasında Çedar peynirlerindeki canlılıklarını korudukları gözlenmiştir. $8^{\circ} \mathrm{C}$ 'de olgunlaşan $\quad$ L. casei 279 ve L. acidophilus 4962 ilavesi yapılan probiyotik peynirlerin daha yüksek proteoliz seviyesine sahip olduğu gözlenmiştir [36].

Ong ve Shah [37], probiyotik mikroorganizmalar 24 hafta sonunda canlı kaldığını (> $7.50 \mathrm{log}$ kob/g) ve yaşama kabiliyetleri olgunlaşma sıcaklıklarından etkilenmemiştir. Kullanılan probiyotik mikroorganizmaların türü, olgunlaşma süresi, olgunlaşma sıcaklıkları ve etkileşimlerinin laktik ve asetik asit konsantrasyonları üzerine önemli etkileri olmuştur $(\mathrm{P}<0.05)$. Bifidobacterium spp. ve/veya L. casei ile yapılan peynirlerin kontrol grubuna göre asetik asit konsantrasyonu önemli ölçüde daha yüksek olduğunu, peynirlerin sitrik, propiyonik ve süksinik asit içerikleri probiyotik mikroorganizma türü veya olgunlaşma sıcaklıklarından önemli ölçüde etkilenmediğini belirtmişlerdir.

Effat vd. [38] çalışmalarında farklı bakteriler (Streptococcus thermophilus ve Lactobacillus delbrueckii ssp. bulgaricus, Lactobacillus johnsonii NRRL B-2178, Lactobacillus hilgardii NRRL B- 
1843 ve Lactobacilus curvatus NBIMCC-3452) ile prebiyotik (dekstrin ve litesse) ilavesinin taze peynir üzerinde uygulamalarını değerlendirmişlerdir. L. curvatus NBIMCC-3452 ve prebiyotikler kullanılarak üretilen peynir uygulamasında canlılık oranı en yüksek, S. thermophilus- L. johnsonii NRRL B- 2178 ve dekstrin ile S. thermophilus-L. curvatus NBIMC 3452 ve litesse duyusal açıdan en yüksek olduğunu belirtmişlerdir.

Yapılan bir çalışma da probiyotik (Lactobacillus rhamnosus GG) kullanılarak pasta filata peynirlerde probiyotik teknolojik parametreleri ayarlamak amaçlanmıştır. Farklı parametreler kullanılarak (pıhtının asitlenmesi ( $\mathrm{pH} 5.25)$ ve süre $(2,5,10$ ve 20 dakika) ve gerdirme sıcaklığı $(58,62.5$ ve 68 ${ }^{\circ} \mathrm{C}$ ) probiyotik bakteri sayısının $10^{7} \mathrm{logkob} / \mathrm{g}$ 'den daha yüksek seviyelerde probiyotik peynir üretilmesi hedeflenmiştir. Sonuç olarak raf ömrü boyunca probiyotik $3 \times 10^{7}$ nin üzerinde kaldığı gözlenmiştir. Probiyotik ilavesi ikincil proteolizi ve diasetil, asetoin, laktik ve asetik asitlerin üretimini arttırdı ̆̆ koku, burukluk, asit tadı gibi duyusal özellikler de değiştirildiği tespit edilmiştir[39].

Probiyotik peynirlerin teknolojik değerlendirmeleri ile ilgili pekçok araştırma bulunmakta, bu derlemede bazılarına yer verilmiştir. Çalışmalar değerlendirildiğinde probiyotik mikroorganizmaların canlı sayısındaki değerlerin çoğunlukla sağlanabildiğini ancak özelikle bazı tür/suşların depolama ile birlikte genellikle glikoliz, lipoliz ve proteoliz olarak adlandırılan çeşitli biyokimyasal ve metabolik işlemlerin bir sonucunda organoleptik özelliklerin değişmesi olumsuzluk olarak belirtilmiştir [40].

\section{PEYNIR ÜRETIMINDE PROBIYYOTIK MIKROORGANIZMALARIN CANLILIĞINI ETKİLEYEN FAKTÖRLER}

Probiyotik mikroorganizmaların çoğu laktik asit bakterileri grubundadır. Laktik asit bakteriler süt ürünlerinde ürünün teknolojik, kalite ve organoleptik özelliklerine katkıları belirtilmesine rağmen, bu mikroorganizmaların uzun süreli canlı kalmaları çok kolay değildir [41]. Starter (başlatan/başlangıç) kültürler süte eklenip, laktik asit oluşumuyla jel sinerezisini etkinleştirir, peynir altı suyu ayrışır ve pıhtı formu oluşur. Kültür için ilave edilen mikroorganizmaların yaklaşık \%90'ı pıhtı içinde tutunur [42]. Jeanson vd. [43] çalışmasında jel kaset model sistemi ile peynir örneklerinde bakteri dağılımını özel mikroskoplar ile dağılımını araştırmışlar ve bakterilerin inokülasyon miktarlarının üretim ve depolamada etkili olduğunu belirlemişlerdir. Bunun sebebi ise bakteriyel enzimlerin peynirde kullandığı alandaki ilişkisi olduğu düşünülmektedir.

Küçük koloni büyüklüğüne sahip peynirlerde serbest yağ asidi seviyesi daha yüksek olduğunu, ayrıca ayırt edici peptitlerin $\sim \% 98$ 'i küçük kolonili peynirlerde olduğunu, diasetil gibi aroma bileşenlerin yine küçük kolonili peynirlerde daha bol olduğunu belirtmiş̧ir [44]. Yazarlara göre parçalanmayan hücrelerden kaynaklı metabolit üretimi peynirde koloni dağılımını etkilediğini, küçük koloni içeren peynirlerde proteaz ve laktosepin daha geniş alana sunulduğunu, substratın kullanılması koloni büyüklüğüne bağlı görünmediğini belirtmişlerdir. Eski peynirlerde yüksek pH'da büyük koloniler protein matriksinde düzensiz bir dağılım gösterirken, düşük pH'ında küçük koloniler eşit olarak dağılım göstermiştir. Peynir matriksinde bakterilerin lokasyonu ve onların metabolik durumları peynir olgunlaşmasında değişime katkı sağlar.

Özellikle olgunlaşma işlemi uygulanan peynirlerin olgunlaşmanın başında $10^{6}-10^{10} \mathrm{kob} / \mathrm{g}$ seviyelerinde olan laktik asit bakterilerinin sayısı, laktozun metabolizması ile laktik asit oluşumu ve pH'nın azalması ile azalmaktadır. Uzun süre depolama ile (genellikle $2-16{ }^{\circ} \mathrm{C}$ 'de) yani olgunlaşma süresince azalmaya devam etmektedir. Ayrıca peynirde kullanılan tuz ve düşük olgunlaşma sıcaklığı gibi faktörlerde bu etkiye katkı sağlamaktadır. Olgunlaşma süreci devam eden peynirlerde protein ve yağların metabolizması sonucu oluşan aroma bileşenleri (aldehitler, ketonlar, alkoller, hidrokarbonlar vs.) bakterileri inhibisyonu sağlamaktadır. Olgunlaşma sırasında meydana gelen birincil biyokimyasal 
değişiklikler, artık laktoz ve sitrat metabolizmasının yanı sıra lipoliz ve proteoliz ile ilgilidir [45]. Daha yüksek bir olgunlaşma sıcaklığının peynirin olgunlaşmasını hızlandırdığı bildirilmiştir.

Peynirdeki probiyotiklerin hayatta kalmasını etkileyen faktörler; formülasyon faktörleri (probiyotik bakteri ve mikrobiyal etkileşimlerin suşları, $\mathrm{pH}$ ve titre edilebilir asitlik, moleküler oksijen, tuz, hidrojen peroksit ve gıda katkı maddeleri, mikrokapsülleme), proses faktörleri (inkübasyon sıcaklığ1, inokülasyon türleri, 1sıl işlem, olgunlaşma faktörleri ve depolama sıcaklığı) ve kullanılan ambalaj malzemeleri ve sistemleridir [46].Peynirin üretimi, kazein moleküllerinin oluşması ve süt pıhtılarının konsantrasyonunu artırmak için süte maya ve laktik asit bakterilerinin eklenmesini içerir. Çöken pıhtılar kalıplanır, preslenir ve tuzlama işlemine tabi tutulur. Peynirlerin karakteristik aromaları ve dokuları, olgunlaşma döneminde, peynirde bulunan bakterilerin lipolitik ve proteolitik aktivitesi ile gelişir [47].

Probiyotikler ile starter kültürler arasındaki etkileşimler olumsuz etkiye neden olabileceği için en uygun probiyotik ve starter kültür kombinasyonları yapılmalıdır [14].

Yeni Zellanda'da 1960-1970'lerde araştırmacılar tek türün olgunlaşmaya etkisi ile ilgili araştırma sonucunda olgunlaşma süresinin türlerin canlılık farklılıklarıyla ilgili olduğunu belirtiyorlar. Düşük canlılı̆̆ın acı aroma oluşmunu sağlamadığını ve starter suş çeşidinin acı yada acısız oluşmada faktör olduğunu belirtiyorlar. Martley ve Lawrence [48] ile Lowrie vd. [49] peynirde yaptıkları araştırmada pişirme sıcaklığı ve tuz oranında bu suşların cevabını oluşturuyor. Lowrie ve Lawrence [50], L. lactis subsp. cremoris acı tat oluşturmadığını, L. lactis subsp. lactis'in ise acı tat oluşturduğunu belirtiyor. Sebebi de şu şekilde açıklanıyor "1sıya ve tuza toleranslı başlangıç suşlarının aktif bir hücre duvarı proteinazına sahip olmasıyla olgunlaşma sırasında acılığın gelişmesine yol açmaktadır". CEP III enzimine sahip suşlar olgunlaşma süresince $\alpha \mathrm{S} 1-\mathrm{CN}$ and $\kappa-\mathrm{CN}$ fragmentlerine hidrolize ederler CEP-I enzimine sahip suşlar ise $\beta$-CN'ni hidrolize ederler. İkincil kazein fragmentleri acı tat oluşumunu sağlar. Olgunlaşma boyunca tek suşun canlılığının azalması, karışık kültüre göre daha kolay olduğunu, klasik mikroorganizma sayım yöntemine göre belirtilmektedir. Wilkinson vd. [51] Çedar peynirinin olgunlaştırılmasında 2-tür olarak G11/C25 kombinasyonu ile AM2 ve HP tek suşları karşılaştırmışlar ve karışık kültürün canlılığının yüksek olduğunu belirlemişlerdir. Suşlar arasındaki farklılıklar ve substrat düzeyindeki değişimlerin belirlenmesi için çok fazla araştırmalar yapılması gerekmektedir. Bunun için klasik yöntemler haricinde kültüre bağlı ve kültürden bağımsız yöntemleri kullanan yaklaşımlar ile suşların karşılaştırılmaları sağlanmalıdır. Peynir üretiminde ise starter kültürlerin otoliz açıklamaları ise oldukça önemlidir; hücrelerin intraselüler enzimleri ve otoliz mekanizmaları gibi [52].

Starter laktik asit bakterileri peynir üretiminde olgunlaştırma ile tipik tekstür ve aroma gelişimi için kullanılması zorunlu bakterilerdir. Probiyotik bakterilerin kullanılması ise olgunlaştırma dönemi için hem sayısal değerinin azalarak amaca uymaması hem de enzim içeriği ile farklı aromların oluşumuna katkı sağlayacak niteliktedir. Peynirde tüm kullanılacak tür ve suşların pişirme sıcaklığına, tuz hassasiyetine ve faj oluşumuna karşı cevabına bağlı karakteristik özelliklerimin belirlenmesi gerekmektedir. Geliştirilecek peynir için kullanılan mikroorganizmanın tüm resmini görebilmek için fenotipik, genotipik karakterlerinin bilinmesi ve üretimde oluşturduğu aroma yolaklarının da belirlenmesi gerekmektedir. Peynir içinde canlılık oranlarının ve morfolojik değişimleri ile ilgili araştırmalarda mikroyapısal özellikleri de belirlenebilir. Ayrıca genomik ve proteomik araştırmalar hücrenin tüm ilişkisi belirlenebilir. Gelecekte akış sitometrisi, tüm genom dizilimi, enzimoloji ve aroma kimyası gibi bilimsel yaklaşımlar ile kullanılan kültürlerin evrimleşmesi hakkında bilgileri sunacaktır. Peynir ortamında otoliz, proteoliz ve nitrojen arasındaki bağlantıların metabolizması bir suşun hayatta kalma stratejisi daha güçlü açıklanacaktır. Tüketicinin yararına yapılan bu uygulamalar akademik ve endüstri açısından önemli olanaklar oluşturacaktır. 


\section{DÜNYA VE TÜRKIYY'DE ENDÜSTRIYYEL ASAMADA PROBIYOTIK PEYNIR ÜRETIM DURUMU}

Fonksiyonel gıdalar, içecekler ve diyet takviyeleri için pazardaki canlılık ve yenilikçilik, mikroorganizmaların sağlığı geliştirmedeki rolü, sürekli klinik araştırma ve probiyotiklerin sunabileceği faydalar hakkında daha fazla farkındalıkla desteklenmektedir. Dünya çapında, probiyotiklere talep olmasının sebebi, son zamanlarda çok sayıda ürün lansmanına ve artan satışlara tanıklık eden fonksiyonel yiyecek/içecek ve tamamlayıcı pazarlar oluşmasıdır. Probiyotik ürünler pazarı, probiyotik yiyecekler ve içecekler, probiyotik takviyeler ve probiyotik hayvan yemlerini içermektedir.

Küresel probiyotik pazarı 2019'da yaklaşık 46.20 Milyar ABD Doları değerindeydi ve 2020 ile 2026 arasında yaklaşık 7.35'lik bir birleşik büyüme oranı ile 75.90 Milyar ABD Dolarına ulaşacağı tahmin ediliyor [53].

Son dört y1lda (2017-2020) genel probiyotik pazarında faaliyet gösteren kilit oyuncular Probi AB (İsveç), BioGaia AB (İsveç), Nestle SA (İsviçre), Chr. Hasen Holding A / S (Danimarka), Danone SA (Fransa), Yakult Honsha Co., Ltd. (Japonya), Lallemand Inc. (Kanada), Lifeway Foods Inc. (ABD), Dupont de Nemours, Inc. (ABD), Kerry Group PLC (İrlanda), Archer Daniels Midland Co. (ABD), Deerland Probiotics \& Enzymes Inc. (ABD), PepsiCo Inc. (ABD), Evolve Biosystems (ABD), Cell BiotechCo., Ltd. (Kore) ve Probiotical SpA (İtalya)'dır [53].Ülkemizde de 2010 y1lından beri Ar-ge firması olan ve kültür üretimi ile perakende satışta yer alan Danem Ltd.Şti. yer almaktadır.

Gıda alanında probiyotiklerin çok farklı ürünlerde kullanımı elbette vardır. Dr. Mark R. Windt (New Hampshire) peynire olan tutkusunu ve tıbbi uzmanlığını, aynı zamanda laktoz ve şeker içermeyen pastörize, probiyotik bir peynir (8-9 log kob/g) geliştirmiş ve Probiotic CheeseCo. (North Hampton)'da canlı kültürler içeren sağlıklı bir probiyotik çedar peynirlerini sade ve farklı aromalı peynirleri Kuzey Atlantik Bölgesi'nde Whole Foods market zincirlerinde pazara sunmaktadır [54]. Family Food Fiesta ve Nancy's firmaları cottage probiyotik peyniri üreten başka bir firmalarıdır. Finger Lakes Dexter Creamery, kefir kullanarak probiyotik peynir yapımı ile 80-90 güne kadar probiyotik canlılığını sağladığını belirtmişlerdir. Bunker Hill Cheese Company firması farklı probiyotik kültür kullanarak sekiz farklı aromada peynirler üretmektedir. 2007'de atılım yapan Kraft'dan Live Active doğal peynir atıştırmalıklarını üretmiştir. Koliforniya'da 50 yıldan fazladır doğal ürünler üreten bir firma olup $2017^{\prime}$ de probiyotik yumuşak krem peynir ürünü ile ürün yelpazesine dahil etmiştir. Bunlar bu pazarda yer alan birkaç probiyotik peynir üreticileridir [55].

Faydalı bağırsak bakterileri olarak bilinen probiyotikler global sıçraması Türkiye'ye de taşıdı, ekmekten bebek mamalarına, dondurmadan yoğurda kadar günlük beslenme alışkanlıklarının tüm süreçlerine yapılan farklı Ar-Ge çalışmalarıyla girmektedir. Bu pazar önümüzdeki 5 yılda 2 kat büyümeye devam edeceği düşünülmektedir.

Türkiye'de peynir tüketimi, 2020 Temmuz ayı verilerine göre yaklaşı 6 milyon ton süt üretiminin inek ve diğer peynirlerin grubundaki üretim miktarı 450 bin ton olarak belirtilmektedir. Süt ürünleri arasında yoğurt ürününden sonra ikinci olarak peynir ürünü yer almaktadır [56]. Ülkemizde probiyotik peynir üretimini Bahçıvan ve Köklü süt ve süt ürünleri yapmaktadır. Ticari olarak kullandıkları probiyotik kültür ile ilgili bilgi verilmemektedir.

\section{V.SONUC}

İnsanların yaşayış şekilleri değiştikçe beslenme alışkanlıkları da değişmektedir. Özellikle genç ve çocuk yaştaki bireyler mikroorganizma içeren fermente ürünleri oldukça az tüketmektedirler. Toplumumuzda tüketilecek -başta bağırsak sağlığımız ve dolaylı olarak bağışıklık sistemimizin 
ihtiyacı olan- yararlı probiyotiklerin alımına alternatif ürünler geliştirmek biz araştırmacılara düşen bir görevdir. Probiyotik mikroorganizmaların alternatif olarak geliştirilecek peynir ürünlerinde kullanılması ile ilgili literatürler ve sektördeki durumu bu derlemede detaylı olarak sunulmuştur.

TEȘEKKÜR: $\mathrm{Bu}$ çalışma Süleyman Demirel Üniversitesi Gıda Müh. Bölümü yüksek lisans programında öğrenci olan Nilüfer Sena Aydoğdu'nun seminer çalışmasıdır.

\section{KAYNAKLAR}

[1] M. Afzaal, A. U. Khan, F. Saeed, A. Ahmed, M. H. Ahmad, A. A. Maan and S.Hussain, "Functional exploration of free and encapsulated probiotic bacteria in yogurt and simulated gastrointestinal conditions," Food Science \& Nutrition, vol. 7, no. 12, pp. 3931-3940,2019.

[2] R. Saxena and N. Gupta, "Health benefits of probiotic fermented foods," Journal of Critical Reviews,vol.7, no. 9, pp. 1344-1348,2020.

[3] F. R. Rolim, O. C. F. Neto, M. E. G.Oliveira, C. J. Oliveira and R. C. Queiroga, "Cheeses as food matrixes for probiotics: In vitro and in vivo tests,"Trends in Food Science \& Technology,vol. 100, pp. 138-154, 2020.

[4] N. P. Shah, "Functional cultures and health benefits," International Dairy Journal, vol.17, no.11, pp. 1262-1277,2007.

[5] S. D. Forssten, C. W. Sindelar and A. C. Ouwehand, "Probiotics from an industrial perspective," Anaerobe, vol. 17, no. 6, pp. 410-413, 2011.

[6] R. Agrawal, "Probiotics: an emerging food supplement with health benefits," Food Biotechnology, vol. 19, no. 3, pp. 227-246, 2005.

[7] Q. G. S. Meira, M. Magnani, F. C. de Medeiros Júnior, R. D. C. R. do Egito, M. S. Madruga, B. Gullón and E. L. de Souza, "Effects of added Lactobacillus acidophilus and Bifidobacterium lactis probiotics on the quality characteristics of goat ricotta and their survival under simulated gastrointestinal conditions," Food Research International, vol. 76, pp. 828-838, 2015.

[8] J. Burgain, C. Gaiani, M. Linder and J. Scher, "Encapsulation of probiotic living cells: From laboratory scale to industrial applications," Journal of Food Engineering, vol. 104, no. 4, pp. 467483, 2011.

[9] F. Ortakci, J. R. Broadbent, W. R. McManus and D. J. McMahon, "Survival of microencapsulated probiotic Lactobacillus paracasei LBC-1e during manufacture of Mozzarella cheese and simulated gastric digestion," Journal of Dairy Science, vol. 95, no. 11, pp. 6274-6281, 2012.

[10] E. Isolauri, Y. Sütas, P. Kankaanpää, H. Arvilommi and S. Salminen, "Probiotics: effects on immunity," The American Journal of Clinical Nutrition, vol. 73, no. 2, pp. 444s-450, 2001.

[11] Türk Gıda Kodeksi Gıda Maddelerinin Genel Etiketleme ve Beslenme Yönünden Etiketleme Kuralları Tebliğinde Değişiklik Yapılması Hakkında Tebliği. (2006, 17 Aralık). heTarım ve Köyiş̧leri Bakanlığ. [Online]. Erişim: https://www.resmigazete.gov.tr/eskiler/2006/07/20060707-14.htm.

[12] B. Özer, H. A. Kirmaci, E. Şenel, M. Atamer and A. Hayaloğlu, "Improving the viability of Bifidobacterium bifidum BB-12 and Lactobacillus acidophilus LA-5 in white-brined cheese by microencapsulation,” International Dairy Journal, vol. 19, no. 1, pp. 22-29, 2009. 
[13] T. Erkaya, "Probiyotik kültürlerle üretilen beyaz peynirlerin olgunlaşma süresince bazı kalite özellikleri ve oluşan peptitlerin biyoaktivitesinin belirlenmesi," Doktora tezi, Fen Bilimleri Enstitüsü, Gıda Mühendisliği, Atatürk Üniversitesi, Erzurum, Türkiye, 2014.

[14] A. G. da Cruz, F. C. A. Buriti, C. H. B. de Souza, J. A. F.Faria and S. M. I. Saad, "Probiotic cheese: health benefits, technological and stability aspects," Trends in Food Science \& Technology, vol. 20, no. 8, pp. 344-354, 2009.

[15] L. Blanchette, D. Roy, G.Belanger and S. F. Gauthier, "Production of cottage cheese using dressing fermented by bifidobaceria," Journal of Dairy Science, vol. 79, no. 1, pp. 8-15, 1996.

[16] M. Gobbetti, A. Corsetti, E. Smacchi, A. Zocchetti and M. DeAngelis, "Production of Crescenza cheese by incorporation of Bifidobacteria," Journal of Dairy Science, vol. 81, pp. 37-47 ,1997.

[17] M. Phillips, K. Kailasapathy and L.Tran, "Viability of commercial probiotic cultures ( $L$. acidophilus, Bifidobacterium sp., L. casei, L. paracasei and L. rhamnosus) in cheddar cheese," International Journal of Food Microbiology, vol. 108, no. 2, pp. 276-280, 2006.

[18] F. C. Buriti, J. S. Da Rocha and S. M. Saad, "Incorporation of Lactobacillus acidophilus in Minas fresh cheese and its implications for textural and sensorial properties during storage," International Dairy Journal, vol. 15, no. 12 , pp. 1279-1288, 2005.

[19] C. V. Bergamini, E. R. Hynes and C. A. Zalazar, "Influence of probiotic bacteria on the proteolysis profile of a semi-hard cheese," International Dairy Journal, vol. 16, no. 8, pp. 856-866. 2006.

[20] B. Özer, H. A. Kirmaci, E. Şenel, M. Atamer and A. Hayaloğlu, "Improving the viability of Bifidobacterium bifidum BB-12 and Lactobacillus acidophilus LA-5 in white-brined cheese by microencapsulation," International Dairy Journal, vol. 19, no. 1, pp. 22-29, 2009.

[21] M. M. Milesi, G. Vinderola, N. Sabbag, C. A. Meinardi and E. Hynes, "Influence on cheese proteolysis and sensory characteristics of non-starter lactobacilli strains with probiotic potential," Food Research International, vol. 42, no. 8, pp. 1186-1196, 2009.

[22] G. E. Gardiner, P. Bouchier, E. O'Sullivan, J. Kelly, J. K. Collins, G. Fitzgerald and C. Stanton, "A spray-dried culture for probiotic Cheddar cheese manufacture," International Dairy Journal, vol. 12, no. 9, pp. 749-756, 2002.

[23] C. V. Bergamini, E. R.Hynes, A.Quiberoni, V. B. Suárez and C. A. Zalazar, "Probiotic bacteria as adjunct starters: influence of the addition methodology on their survival in a semi-hard Argentinean cheese,"Food Research International, vol. 38, no. 5, pp. 597-604,2005.

[24] A. A. Gomes, S. P. Braga, A. G. Cruz, R. S. Cadena, P. C. B. Lollo, C. Carvalho and H. M. A. Bolini, "Effect of the inoculation level of Lactobacillus acidophilus in probiotic cheese on the physicochemical features and sensory performance compared with commercial cheeses," Journal of Dairy Science, vol. 94, no. 10, pp. 4777-4786, 2011.

[25] C. V. Bergamini, E. R. Hynes, S. B. Palma, N. G. Sabbag and C. A. Zalazar, "Proteolytic activity of three probiotic strains in semi-hard cheese as single and mixed cultures: Lactobacillus acidophilus, Lactobacillus paracasei and Bifidobacterium lactis," International Dairy Journal, vol. 19, no. 8, pp. 467-475, 2009. 
[26] G. Vinderola, W. Prosello, F. Molinari, D. Ghiberto and J. Reinheimer, "Growth of Lactobacillus paracasei A13 in Argentinian probiotic cheese and its impact on the characteristics of the product," International Journal of Food Microbiology, vol. 135 , no. 2, pp. 171-174, 2009.

[27] M. H. Fortin, C. P. Champagne, D. St-Gelais, M. Britten, P. Fustier and M. Lacroix, "Effect of time of inoculation, starter addition, oxygen level and salting on the viability of probiotic cultures during Cheddar cheese production," International Dairy Journal, vol. 21, no. 2, pp. 75-82, 2011.

[28] M. Scheller and D. J. O'Sullivan, "Comparative analysis of an intestinal strain of Bifidobacterium longum and a strain of Bifidobacterium animalis subspecies lactis in Cheddar cheese," Journal of Dairy Science, vol. 94, no. 3, pp. 1122-1131, 2011.

[29] F. Minervini, S. Siragusa, M. Faccia, F. Dal Bello, M. Gobbetti and M. De Angelis, "Manufacture of Fior di Latte cheese by incorporation of probiotic lactobacilli," Journal of Dairy Science, vol. 95, no. 2, pp. 508-520, 2012.

[30] H. Mirzaei, H. Pourjafar and A. Homayouni, "Effect of calcium alginate and resistant starch microencapsulation on the survival rate of Lactobacillus acidophilus La5 and sensory properties in Iranian white brined cheese," Food Chemistry, vol. 132, no. 4, pp. 1966-1970, 2012.

[31] B. Özer, Y. S. Uzun and H. A. Kirmaci, "Effect of microencapsulation on viability of Lactobacillus acidophilus LA-5 and Bifidobacterium bifidum BB-12 during Kasar cheese ripening," International Journal of Dairy Technology, vol. 61, no. 3, pp. 237-244, 2008.

[32] K. M. Amine, C. P. Champagne, Y. Raymond, D. St-Gelais, M. Britten, P. Fustier and M. Lacroix, "Survival of microencapsulated Bifidobacterium longum in Cheddar cheese during production and storage," Food Control, vol. 37, pp. 193-199, 2014.

[33] A. Kasımoğlu, M. Göncüoğlu and S. Akgün, "Probiotic white cheese with Lactobacillus acidophilus," International Dairy Journal, vol. 14, no. 12, pp. 1067-1073, 2004.

[34] M. Albenzio, A. Santillo, M. Caroprese, D. Ruggieri, F. Napolitano and A. Sevi, "Physicochemical properties of Scamorza ewe milk cheese manufactured with different probiotic cultures," Journal of Dairy Science, vol. 96, no. 5, pp. 2781-2791, 2013.

[35] P. Burns, F. Cuffia, M. Milesi, G. Vinderola, C. Meinardi, N. Sabbag and E. Hynes, "Technological and probiotic role of adjunct cultures of non-starter lactobacilli in soft cheeses," Food Microbiology, vol. 30, no. 1, pp. 45-50, 2012.

[36] L. Ong and N. P. Shah, "Release and identification of angiotensin-converting enzymeinhibitory peptides as influenced by ripening temperatures and probiotic adjuncts in Cheddar cheeses," LWT-Food Science and Technology,vol. 41, no. 9, pp. 1555-1566, 2008.

[37] L. Ong and N. P. Shah, "Probiotic Cheddar cheese: Influence of ripening temperatures on survival of probiotic microorganisms, cheese composition and organic acid profiles," LWT-Food Science and Technology, vol. 42, no. 7, pp. 1260-1268, 2009.

[38] B. A. Effat, A. M. Mabrouk, Z. I. Sadek, G. A. Hussein and M. N. Magdoub, "Production of novel functional white soft cheese," Journal of Microbiology, Biotechnology and Food Sciences, vol. 2021, pp. 1259-1278, 2021.

[39] F. Cuffia, G. George, P. Renzulli, J. Reinheimer, C. Meinardi and P. Burns, "Technological challenges in the production of a probiotic pasta filata soft cheese," LWT-Food Science and Technology, vol. 81, pp. 111-117, 2017. 
[40] N. Y. Farkye, "Cheese technology," International Journal of Dairy Technology, vol. 57, no. 2-3, pp. 91-98, 2004.

[41] P. de Vos, M. M. Faas, M. Spasojevic and J. Sikkema, "Encapsulation for preservation of functionality and targeted delivery of bioactive food components," International Dairy Journal, vol. 20, no. 4, pp. 292-302, 2010.

[42] I. A. Doolan, A. B. Nongonierma, K. N. Kilcawley and M. G. Wilkinson, "Partitioning of starter bacteria and added exogenous enzyme activities between curd and whey during Cheddar cheese manufacture," International Dairy Journal, vol. 34, no. 1, pp. 159-166, 2014.

[43] S. Jeanson, J. Chadoeuf, M. N. Madec, S. Aly, J. Floury, T. F. Brocklehurst and S. Lortal, "Spatial distribution of bacterial colonies in a model cheese," Applied and Environmental Microbiology, vol. 77, no. 4, pp. 1493, 2011.

[44] C. Le Boucher, V. Gagnaire, V. Briard-Bion, J. Jardin, M. B. Maillard, G. Dervilly-Pinel and A. Thierry, "Spatial distribution of Lactococcus lactis colonies modulates the production of major metabolites during the ripening of a model cheese," Applied and Environmental Microbiology, vol. 82, no. 1, pp. 202, 2016.

[45] P. L. H. McSweeney and P. F. Fox, "Metabolism of residual lactose and of lactate and citrate," Cheese: Chemistry, Physics and Microbiology, vol. 1, pp. 361-371, 2004.

[46] R. Karimi, A. M. Mortazavian and A. G. Da Cruz, "Viability of probiotic microorganisms in cheese during production and storage: a review," Dairy Science \& Technology, vol. 91, no. 3, pp. 283-308, 2011.

[47] T. D. Boylston, C. G. Vinderola, H. B. Ghoddusi and J. A. Reinheimer, "Incorporation of bifidobacteria into cheeses: challenges and rewards," International Dairy Journal, vol. 14, no. 5, pp. 375-387, 2004.

[48] F. G. Martley and R. C. Lawrence, "Cheddar cheese flavour. II. Characteristics of single strain starters associated with good or poor flavour develop ment," NZJ Dairy Technol, vol. 7, pp.38, 1972.

[49] R. J. Lowrie, R. C. Lawrence and L. E. Pearce, "Cheddar cheese flavour. III. The growth of lactic streptococci during cheesemaking and the effect on bitterness development." NZJ Dairy Technol, vol. 7, pp. 44, 1972.

[50] R. J. Lowrie and R. C. Lawrence, "Cheddar cheese flavour. IV. A new hypothesis to account for the development of bitterness," NZJ Dairy Technol, vol. 7, pp. 52, 1972.

[51] M. G. Wilkinson, T. P. Guinee, D. M. O'Callaghan, P. F. Fox, "Autolysis and proteolysis in different strains of starter bacteria during Cheddar cheese ripening," Journal of Dairy Research, vol.61, no. 2, pp. 249-262, 1994.

[52] M. G. Wilkinson, G. LaPointe, "Invited review: Starter lactic acid bacteria survival in cheese: New perspectives on cheese microbiology," Journal of Dairy Science, vol. 103, no. 12, pp. 10963 10985, 2020.

[53] "Global Probiotics Market (2020 to 2025) - by Product Type, Strain, Form, Sales Channel, and Geography," (2020, 17 Aralık). [Online]. Available: https://www.globenewswire.com/newsrelease/2020/10/08/2105400/0/en/Global-Probiotics-Market-2020-to-2025-by-Product-Type-StrainForm-Sales-Channel-and-Geography.html. 
[54] The Probiotic Cheese Company, Think USA Dairy Site, (2018, 17 Aralı). [Online]. Available: https://www.thinkusadairy.org/us-specialty-cheese-gallery/new-hampshire/the-probioticcheese-company.

[55] S. Zonıs, " Probiotic Foods-Part IV: Foods Containing Probiotics, Prebiotics Or Both Lassi, Cheese \& Kefir," (2020, 15 Aralık).[Online]. Available:http://76.12.135.232/reviews/nutri/probioticfoods4.asp.

[56] Süt ve Süt Ürünleri Üretim İstatistikleri, TUIK, Sayl:33701, (2020, 10 Aralık) [Online]. Available: https://tuikweb.tuik.gov.tr/HbPrint.do?id=33701. 